\title{
The Treatment of Stress Incontinence in Men
}

\author{
Part 2 of a Series of Articles on Incontinence
}

Christof Börgermann, Albert Kaufmann, Herbert Sperling, Manfred Stöhrer, Herbert Rübben

\section{SUMMARY}

Background: Stress incontinence in men is a rare, usually iatrogenic condition. Its prevalence can be expected to rise in the future because of the increasingly common performance of radical prostatectomy. Most men who have undergone prostatectomy experience a transient disturbance of urinary continence. Such disturbances are only rarely due to structural damage to the sphincter apparatus and therefore have a good prognosis for spontaneous recovery.

\section{Method: Selective literature review.}

Results: Pelvic floor training and/or pharmacotherapy can be used for more rapid restoration of subjectively satisfactory urinary continence. If the sphincter is intact, continence can also be regained in the early postoperative period through the submucosal injection of bulking agents. Incontinent patients whose urinary sphincter is dysfunctional because of denervation or direct injury to striated muscle can now be treated with a variety of surgical techniques. The implantation of an artificial sphincter is the gold standard of therapy. Properly selected and informed patients can also be treated with minimally invasive procedures, such as the creation of a male suburethral sling, although the experience with such procedures to date has not been extensive.

Conclusion: Post-prostatectomy incontinence has a good prognosis and should thus be treated conservatively at first. If it nonetheless persists, surgical treatment is indicated for patients who choose it after being fully informed about their options.

\section{Gite this as: Dtsch Arztebl Int 2010; 107(27): 484-91} DOL: 10.3238/arztebl.2010.0484

Klinik für Urologie, Kinderurologie und Uroonkologie, Krankenhaus Düren gGmbH: Dr. med. Börgermann

Zentrum für Kontinenz und Neuro-Urologie, Kliniken Maria Hilf, Mönchengladbach: Dr. med. Kaufmann

Klinik für Urologie, Kliniken Maria Hilf, Mönchengladbach: PD Dr. med. Sperling

Klinik für Urologie, Uroonkologie und Kinderurologie, Universitätsklinikum Essen: Prof. Dr. med. Stöhrer, Prof. Dr. med. Dr. h. c. Rübben
$T$ he most common cause of stress incontinence in men is iatrogenically or traumatically induced insufficiency of the external urethral sphincter (e1). The rate of incontinence after radical prostatectomy, as reported in the literature, ranges from just below $1 \%$ to $90 \%$ (1-3). This very wide divergence of reported incontinence rates can be traced to differences in operative technique as well as to divergent definitions of incontinence. Prostate surgery has undergone major technical refinements in recent years. The nerves can be preserved more often today than in the past, because the relevant anatomy is better understood. Definitions of "continence" range from total dryness to the use of multiple incontinence pads per day. A further important aspect is the time point at which continence is assessed. Nearly all patients experience transient stress incontinence of the first or second degree. The problem is usually due, at first, to irritative symptoms and the urge incontinence associated with them; this is combined with weakness of the remaining external sphincter muscle, which faces a more difficult task than in the physiological situation, as structures adjacent to it that normally provide additional resistance have been surgically removed. In general, there is a good prognosis for the return of continence within one year after surgery (Figure 1) $(4,5)$.

Stress incontinence markedly impairs the quality of life of the affected men, who regard the need to wear incontinence pads as even more bothersome than postoperative erectile dysfunction (6). As the population as a whole ages, pelvic surgery will become more common and we will be confronted with the problem of postoperative stress incontinence in ever greater numbers of men, despite improvements in surgical and radiotherapeutic technique. The current prevalence of stress incontinence in men is below 1\% (7).

The desire for social continence is strong, and many different therapeutic innovations have been designed for this purpose. Social continence is defined as the ability of the patient to participate in his normal social activities without limitation. This usually corresponds to the use of no more than one incontinence pad per day.

We here present the treatment options for stress incontinence in men and discuss them critically. This 
article is based on a selective search for relevant literature in the database of the U. S. National Library of Medicine. We performed a general search for the terms "male stress incontinence" and "post-prostatectomy incontinence," as well as specific searches for each of the individual therapeutic and surgical techniques under discussion. Prospective randomized studies are lacking for many of them, and thus the overall state of the evidence is weak.

\section{Pathogenesis and diagnostic evaluation}

Continence after prostatectomy depends on pre-, intra-, and postoperative factors. The preoperative factors include the patient's age and continence status before surgery. Intraoperatively, nerve preservation, the surgeon's experience, and preservation of the neck of the bladder all play an important role. Postoperatively, good patient compliance can be helpful; the pelvic floor can also undergo postoperative changes (sinking) (8).

The most important step in the treatment of stress incontinence in men is active discussion of the subject—still sometimes wrongly regarded as taboo-between the physician and the patient. Men who have undergone pelvic surgery should be directly asked by their doctors about their continence situation. Thus, the initial diagnostic step is history-taking, including a medication history and any associated illnesses. Next, a physical examination is performed, including both a digital rectal examination and a directed neurological examination of the sacral region. Ultrasonography for the measurement of residual urine volume, urinalysis, a PAD test, a voiding diary, and an incontinence questionnaire all yield useful supplementary information (e.g., the Incontinence Questionnaire-Short Form, ICIQ-SF). After this basic diagnostic evaluation, some form of conservative therapy can be initiated, such as pelvic floor training, biofeedback, electrostimulation, or pharmacotherapy. If these measures are ineffective, further diagnostic assessment with cystoscopy, urodynamic testing, and (in some cases) radiological studies is performed, after which surgical treatment options may have to be considered. These range from minimally invasive techniques, such as the paraurethral injection of bulking agents, to sling plasties and to the implantation of artificial sphincter systems (Figure 2) (e2).

\section{Conservative treatment \\ Pelvic floor training, biofeedback, electrostimulation, magnetic field stimulation}

The initial option in the treatment of post-surgical stress incontinence is pelvic floor training, which is sometimes combined with biofeedback. Two Cochrane meta-analyses from the years 2004 and 2007 involved a tabulation of results from 6 and 10 randomized studies, respectively, and yielded the finding that continence improved more rapidly in patients who underwent pelvic floor training than in control patients. This difference, however, was no longer significant 6 to 12 months after surgery (Table 1$)(9,10)$. The main role of

\section{GASE ILLUSTRATION}

A 52-year-old man presented with recurrent stress incontinence twelve months after radical prostatectomy for localized prostatic carcinoma. He had suffered from stress incontinence after surgery and had undergone a transobturator sling plasty to treat it, with very good initial results. Later on in his postoperative course, a penile prosthesis was implanted to treat erectile dysfunction. From then onward, he noted increased involuntary loss of urine, particularly when the prosthesis was activated. To investigate this problem, A PAD test was performed and revealed $36 \mathrm{~mL}$ of urine loss per hour. Cystoscopy revealed a normal-appearing bladder, with a morphologically intact sphincter apparatus. A urodynamic study revealed a bladder capacity of $450 \mathrm{~mL}$ and no autonomous detrusor contractions Provocation by coughing induced urinary dribbling, and the outlet resistance was diminished. On the basis of these findings, a neurogenic disturbance of the sphincter apparatus was diagnosed. Improved continence had been achieved, at first, by repositioning the bladder neck with the sling plasty; later, however, the bladder neck and the sling plasty were displaced caudally each time the cylinders of the implanted penile prosthesis were inflated, resulting in recurrent incontinence. This new problem was treated with the implantation of an artificial sphincter. Thereafter, the patient needed to use only one small incontinence pad per day. He said that he was losing only negligible amounts of urine, even when the penile prosthesis was activated. A PAD test revealed 1 to $2 \mathrm{~mL}$ of urine loss per hour.

\section{FIGURE 1}

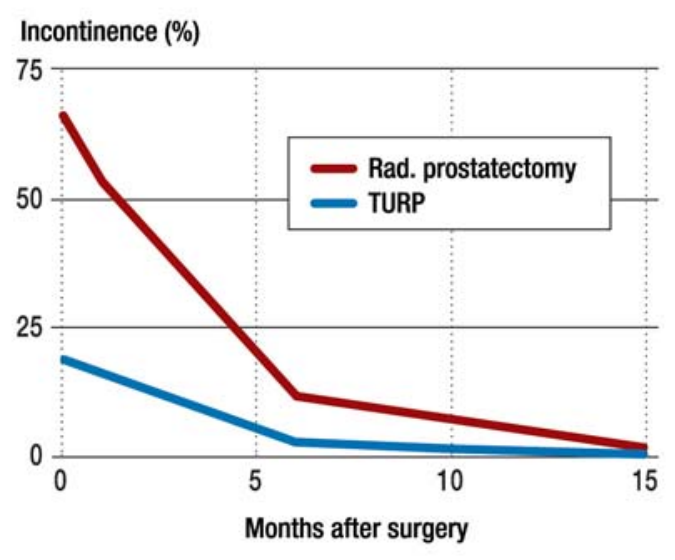

pelvic floor training is thus to shorten the period of incontinence that normally ends in any case when the condition takes its usual, favorable spontaneous course.

Electrical and magnetic field stimulation are two further options for physical therapy. In a three-armed study comparing pelvic floor training with electrical and magnetic field stimulation, the loss of urine was initially comparable in all three groups (more than 650 g per 24 hours in each). At 4 weeks, however, the magnetic and electrical stimulation groups were found to have a significantly smaller loss of urine than the pelvic floor training group (72 and $83 \mathrm{~g} / 24 \mathrm{~h}$, respectively, compared to $175 \mathrm{~g} / 24 \mathrm{~h})$. At 6 months, the three groups no longer differed from one another, with the daily loss of urine being less than $10 \mathrm{~g}$ in all three (11). 
FIGURE 2

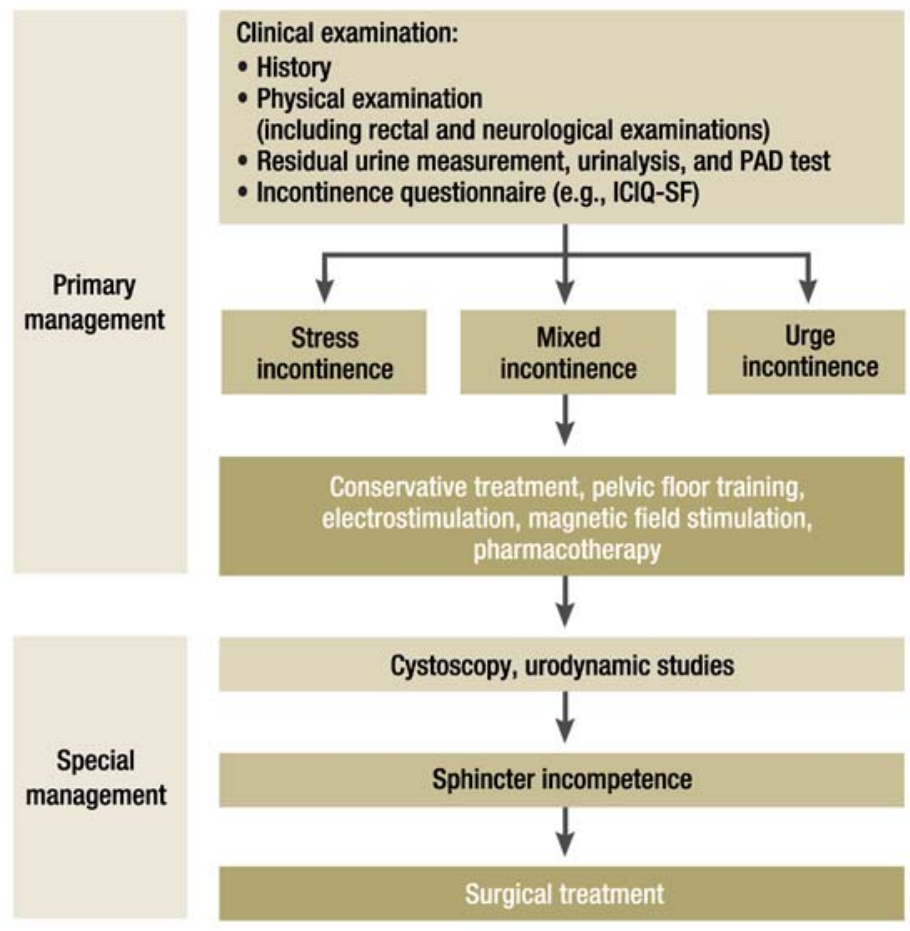

A diagnostic and therapeutic algorithm for the management of stress incontinence after radical prostatectomy (modified from the 2009 EAU guideline [e2]); ICIQ-SF, Incontinence Questionnaire-Short Form

\section{TABLE 1}

Comparison of two Cochrane meta-analyses*1

\begin{tabular}{l|l|l|l} 
Author & $\begin{array}{l}\text { Number of } \\
\text { studies }\end{array}$ & Treatment & Outcome \\
\hline $\begin{array}{l}\text { Hunter et al. 2004 } \\
(9)\end{array}$ & 6 & $\begin{array}{l}\text { Pelvic floor training } \\
\text { Biofeedback }\end{array}$ & $\begin{array}{l}\text { No significant } \\
\text { difference at } \\
\text { Electrostimulation } \\
\text { Con } 12 \text { months }\end{array}$ \\
\hline $\begin{array}{l}\text { Moore et al. } 2007 \\
(10)\end{array}$ & 10 & & \\
\hline
\end{tabular}

${ }^{1}$ These meta-analyses showed no significant advantage of conservative (non-surgical) treatment over the spontaneous course of the condition at 6 or 12 months

\section{Pharmacotherapy}

Many published case series concern the pharmacological treatment of stress incontinence in men. Table 2 provides an overview of the medications that have been tried. Even in the series with good results, the level of evidence is poor. The serotonin and noradrenaline reuptake inhibitor duloxetine is a new treatment option. It improves continence through relaxation of the detrusor muscle and simultaneous contraction of urethral smooth muscle, as well as increased tone in the striated muscle of the sphincter, which is mediated by Onuf's nucleus in the sacral segments of the spinal cord. In a randomized study of 112 men who had undergone radical prostatectomy, the patients who were taking duloxetine had significantly better continence-related life quality parameters in the first 16 weeks than the patients in the control group (12). This drug, however, has not been approved for the treatment of stress incontinence in men, and is thus an off-label application at present. The patient must be informed of this fact, and the conversation should be documented in the patient's chart, before any treatment with duloxetine is begun.

\section{Surgical treatment}

If primary conservative therapy fails and the findings of a further diagnostic evaluation warrant surgery, a variety of surgical procedures are available to treat postoperative stress incontinence.

\section{Paraurethral injection therapy-sphincter injection therapy_-bulking agents}

For over 40 years, submucosal injections of many different substances have been tried as a means of adapting the urethral mucosa so that it can support the sphincter apparatus, with resulting urinary continence. A variety of biodegradable and non-biodegradable substances are in use. The most commonly used substances today are polydimethylsiloxane and dextranomerhyaluronic acid copolymer. Many studies have shown that the injection of bulking agents improves continence by at least one degree in a large percentage of patients (up to 97\%). It must be noted, however, that most of these studies were small, nonrandomized case series, and thus the overall level of evidence is low. Table 3 provides an overview of the relevant publications.

In our own case series of bulking with polydimethylsiloxane, improvement was obtained by $93 \%$ of men with first- or second-degree incontinence, but only 59\% of men with third-degree incontinence. The timing of treatment also seems to be critical. Patients who are treated early with sphincter injection therapy (in order, one might say, to hasten the slow spontaneous improvement that would occur without it) apparently benefit the most from it, while those who have been incontinent for more than one year are less likely to respond to treatment (13). Loss of the therapeutic effect is another problem: A repeated intervention is often needed, yet reinjection of the substance can induce an inflammatory reaction leading to scarring of the submucosal vascular plexus and thus to an impairment of urethral elasticity and of the passive function of the closure apparatus. The final result may be a "frozen urethra," which can make further treatment even more difficult (3). Injections of bulking agents cause no additional difficulties for the subsequent performance of alloplastic sphincter implantation, as long as the injections are performed for proper indications and with correct technique, i.e., under direct vision and exclusively in the area of the sphincter (14).

\section{Paraurethral balloon compression}

The system consists of a balloon connected by a tube $12 \mathrm{~cm}$ to $14 \mathrm{~cm}$ in length to an injection port through which the degree of balloon inflation can be adjusted. It 


\section{TABLE 2}

Overview of clinical trials of pharmacotherapy for stress incontinence in men.

\begin{tabular}{|c|c|c|c|c|}
\hline Medication & n (Men) & Study type & Outcome & Author \\
\hline \multicolumn{5}{|c|}{ Alpha agonists } \\
\hline Ephedrine & $\begin{array}{l}20 \\
(+18 \text { women })\end{array}$ & Case series & 27 / 38 (71.1\%) no incontinence or drops only & Diokno et al. (e3) \\
\hline Midodrine & 5 & Case series & 5 / 5 (100\%) improvement & Nito et al. (e4) \\
\hline \multicolumn{5}{|c|}{ Beta agonists } \\
\hline Glenbuterol & 14 & Cohort study & $9 / 14(64.3 \%)$ reduced use of incontinence pads & Noguchi et al. (e5) \\
\hline Glenbuterol & 72 & Case series & 55 / 72 (76.3\%) fully continent & Zozikov et al. (e6) \\
\hline \multicolumn{5}{|c|}{ Serotonin- and noradrenaline-reuptake inhibitors } \\
\hline Imipramine & 5 & Case series & $3 / 5(60 \%)$ improvement or cure & Reid et al. (e7) \\
\hline Duloxetine & 20 & Case series & $7 / 18(38.9 \%)^{*}$ reduced use of incontinence pads & Schlenker et al. (e8) \\
\hline Duloxetine & 18 & Case series & $46.7 \%$ less loss of urine (from 124 to $58 \mathrm{~g}$ by PAD test) & Zahariou et al. (e9) \\
\hline Duloxetine & 112 & $\begin{array}{l}\text { Randomized } \\
\text { trial }\end{array}$ & $\begin{array}{l}39 \text { / } 50(78 \%) \text { (treatment arm) vs. } 27 \text { / } 52(51.9 \%) \\
\left(\text { placebo arm) }{ }^{\star}\right. \\
\text { Reduced use of incontinence pads at } 16 \text { weeks }\end{array}$ & Filocamo et al. (12) \\
\hline
\end{tabular}

${ }^{* 1}$ significant differences

\section{TABLE 3}

Overview of paraurethral injection therapy for urethral bulking in the treatment of stress incontinence in men

\begin{tabular}{|c|c|c|c|c|}
\hline Medication & N & Study type & Outcome & Author \\
\hline Polydimethyl-siloxane & 50 & Case series & $\begin{array}{l}34 \text { / } 50(68 \%) \text { improvement after the 1st injection, } \\
42 \text { / } 50(84 \%) \text { after the } 2 \text { nd injection }\end{array}$ & Kylmala et al. (e10) \\
\hline Polydimethyl-siloxane & 23 & $\begin{array}{l}\text { Randomized } \\
\text { trial }\end{array}$ & $\begin{array}{l}8 / 10(80 \%) \text { improvement of 1st- or 2nd-degree incontinence, } \\
3 \text { / } 13(23 \%) \text { improvement of 3rd-degree incontinence at } 48 \\
\text { months }\end{array}$ & Imamoglu et al. (e11) \\
\hline Polydimethyl-siloxane & 44 & Case series & $\begin{array}{l}14 \text { / } 15 \text { (93\%) improvement of 1st- or 2nd degree incontinence, } \\
17 \text { / } 29 \text { (59\%) improvement of 3rd-degree incontinence at } 26 \\
\text { months }\end{array}$ & Schneider et al. (13) \\
\hline $\begin{array}{l}\text { Dextranomer-hyalu- } \\
\text { ronic acid copolymer }\end{array}$ & 72 & Case series & $70 / 72$ (97\%) improvement at 4-8 weeks & Alloussi et al. (e12) \\
\hline
\end{tabular}

\section{FIGURE 3}

a

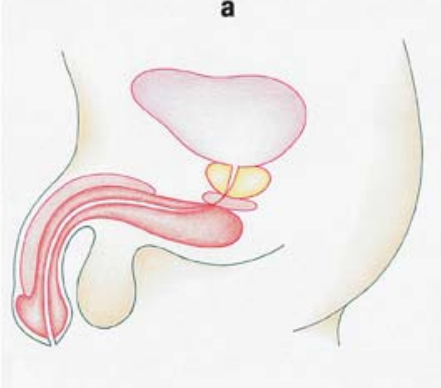

b

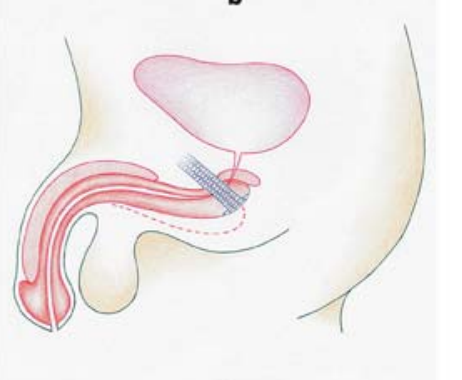

The underlying principle of sling plasty in

the male patient: passive, semi-

circumferential urethral compression 
TABLE 4

Overview of sling and balloon compression systems for the surgical treatment of stress incontinence in men

\begin{tabular}{|c|c|c|c|c|}
\hline $\begin{array}{l}\text { Type of compression } \\
\text { system }\end{array}$ & $\mathrm{n}$ & Study type & Outcome & Author \\
\hline \multirow[t]{2}{*}{ Balloon } & 117 & Case series & $\begin{array}{l}105 \text { / } 117(90 \%) \text { improvement, } \\
32 \text { / } 117(27,4 \%) \text { revisions at } 13 \text { months }\end{array}$ & Hubner et al. (e13) \\
\hline & 62 & Case series & 36 / 62 (59\%) improvement, 19 / 62 (30,6\%) revisions & Lebret et al. (e14) \\
\hline $\begin{array}{l}\text { Autologous fascial } \\
\text { sling }\end{array}$ & 20 & Case series & Use of incontinence pads reduced from 7.8 to 1.5 per day & Thüroff et al. (e16) \\
\hline \multirow[t]{2}{*}{ Sling attached to bone } & 16 & Case series & $\begin{array}{l}14 \text { / } 16(88 \%) \text { continent at } 12.2 \text { months, } \\
\text { no complications or non-responders }\end{array}$ & Madjar et al. (e17) \\
\hline & 50 & Case series & 38 / 50 (76\%) improvement, 12 / 50 (24\%) non-responders & Fassi-Fehri et al. (e18) \\
\hline \multirow[t]{2}{*}{ Adjustable sling } & 51 & Case series & $\begin{array}{l}43 \text { / } 51(84,3 \%) \text { improvement, } \\
8 / 51(15,7 \%) \text { non-responders at } 32 \text { months }\end{array}$ & Sousa et al. (e19) \\
\hline & 48 & Case series & $\begin{array}{l}35 \text { / } 48 \text { ( } 73 \%) \text { cure rate, } \\
\text { no major complications at } 7.5 \text { months }\end{array}$ & Romano et al. (e20) \\
\hline \multirow[t]{3}{*}{ Trans-obturator sling } & 20 & Case series & 17 / 20 (85\%) improvement, no major complications & De Leval et al. (e21) \\
\hline & 20 & Case series & 14 / 20 (70\%) improvement & Rheder et al. (e22) \\
\hline & 67 & Case series & 60 / 67 (90\%) improvement & Gozzi et al. (e23) \\
\hline
\end{tabular}

Figure 4:

The AMS 800 artificial sphincter consists of three components:

1. A pump to empty the cuff and permit micturition

2. A pressure-regulating balloon for the transmission of a defined pressure to the cuff

3. A cuff for urethral compression

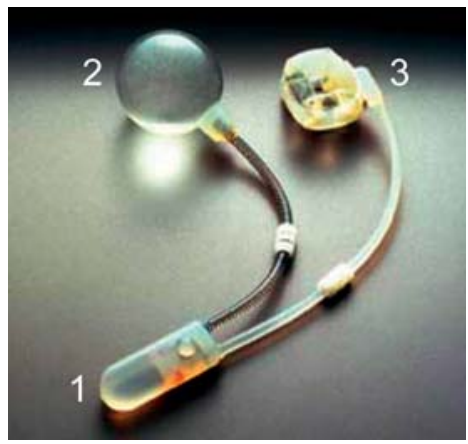

is implanted through a perineal incision under x-ray guidance. One balloon is positioned on either side of the bladder neck, and $1 \mathrm{~mL}$ of contrast solution is instilled into each. The two ports are placed under the skin of the scrotum. Once the system has healed into place, the balloons are filled in small increments through their respective ports, until satisfactory continence is achieved. In two case series, continence improved in 59\% and $90 \%$ of patients, but the revision rates were high: $27.4 \%$ and $30.6 \%$ (e13, e14). Serious complications of paraurethral balloon implantation, including rectal perforation, have also been described (e15).

\section{Suburethral slings ("male slings")}

The first publication on sling plasty as a treatment of urinary incontinence in men appeared at the beginning of the 20th century. The method is based on the principle of passive, semi-circumferential urethral compression. This does not impair perfusion of the dorsal portion of the urethra and thus carries a lower risk of urethral atrophy than artificial sphincter implantation (Figure 3) (15). Many modifications of the method have been described, involving the use of different materials for the spring as well as various different surgical approaches, positions for the sling, and methods for placing and anchoring it. Among the many sling systems available, we have selected a few for brief discussion in the following paragraphs.

\section{Autologous fascial strips}

Thüroff et al. successfully used an autologous fascial sling, passed around the bulbous urethra and anchored to the rectus fascia, in 20 patients (e16). The average daily use of incontinence pads was reduced from 7.8 to 1.5. The drawback with this technically demanding operation is that it requires precise setting of the sling tension so that the patient can achieve adequate continence without overcorrection (4).

\section{Sling systems anchored to bone}

In systems of this type, a silicon-coated prolene mesh is anchored to the pubic bone with six bone screws in such a way that it passes around the bulbous urethra, raising the urethral resistance by $60 \mathrm{~cm} \mathrm{H}_{2} \mathrm{O}$. Compressing the urethra in this way improves continence.

\section{Adjustable sling systems}

In these systems, a prolene sling is connected to a so-called variotensor device that lies superficial to the 


\section{TABLE 5}

Continence state and complications after the implantation of an artificial sphincter system

\begin{tabular}{|c|c|c|c|}
\hline Author & $\mathrm{n}$ & Study type & Outcome \\
\hline Perez et al. (19) & 75 & Case series & $\begin{array}{l}56 \text { / } 75 \text { (75\%) max. } 1 \text { incontinence } \\
\text { pad }\end{array}$ \\
\hline Fleshner et al. (18) & 30 & Case series & $\begin{array}{l}26 \text { / } 30 \text { (87\%) max. } 1 \text { incontinence } \\
\text { pad }\end{array}$ \\
\hline Trigo-Rocha et al. (20) & 40 & $\begin{array}{l}\text { Prospective } \\
\text { trial }\end{array}$ & $\begin{array}{l}36 \text { / } 40 \text { (90\%) max. } 1 \text { incontinence } \\
\text { pad, } 8 \text { / } 40 \text { (20\%) revisions at } 53 \\
\text { months }\end{array}$ \\
\hline Montague et al. (21) & 166 & Case series & $\begin{array}{l}\text { Up to } 10 \% \text { infection of the system } \\
\text { by } 41 \text { months }\end{array}$ \\
\hline Elliott et al. (24) & 400 & Case series & $\begin{array}{l}1-3 \% \text { urethral erosion at } 68.8 \\
\text { months }\end{array}$ \\
\hline Litwiller et al. (23) & 65 & Case series & $\begin{array}{l}3-9 \% \text { urethral atrophy at } 23.4 \\
\text { months }\end{array}$ \\
\hline Leo et al. (25) & 144 & Case series & $\begin{array}{l}12 \text { / } 144(8 \%) \text { system defects by } 28 \\
\text { months }\end{array}$ \\
\hline
\end{tabular}

\section{TABLE 6}

Evidence levels and recommendation grades for different methods of treatment ${ }^{* 1}$

\begin{tabular}{l|l|l} 
Method of treatment & Evidence level & $\begin{array}{l}\text { Recommen- } \\
\text { dation grade }\end{array}$ \\
\hline Pelvic floor training & 2 & B \\
\hline Duloxetine & $3-4$ & C \\
\hline Paraurethral injection & 3 & B \\
\hline Sling systems & 3 & B \\
\hline $\begin{array}{l}\text { Artificial sphincter } \\
\text { systems }\end{array}$ & 1 & A \\
\hline
\end{tabular}

rectus fascia. The sling tension can be adjusted afterward with a screw mechanism.

\section{Trans-obtuator suburethral bands}

Just as in the treatment of incontinence in women, a prolene sling can be pulled through the obturator foramen to correct post-surgical pelvic floor sinking in men. The system is passed around the bulbous urethra, and its two ends are pulled up. The pelvic floor is thereby elevated without tension and the urethra is restored to its normal position, with improved continence as the result. This mechanism is a unique feature of trans-obturator bands among all types of sling systems.

A number of case series of balloon compression and sling plasties are presented in Table 4. In summary, these minimally invasive surgical methods yield satisfactory rates of continence for mildly or moderately incontinent patients, with a low rate of complications. Their advantage over an artificial sphincter lies in the ease of implantation. Nonetheless, the currently available data do not permit any definitive judgment on these promising techniques.

\section{Artificial urethral sphincter}

The artificial sphincter is the gold standard in the treatment of stress incontinence in men. No other method achieves comparable continence rates in patients with post-prostatectomy incontinence (8). The concept of treatment is to mimic the natural function of the sphincter muscle with circumferential compression of the bladder outlet. The first artificial sphincter system was implanted in 1972 by Scott, Bradley, and Timm (16). Their system has since undergone many modifications, leading up to the model that is currently used (Figure 4). Other systems exist as well, such as that of Craggs (17), which includes a second pressure balloon that raises the pressure in the system when the intraabdominal pressure rises. Unlike all other methods, which exert a steady, continuous pressure, the hydraulic sphincter exerts a variable degree of resistance to urinary outflow.

The cuff is placed around the bulbous urethra to treat post-prostatectomy incontinence, or at the neck of the bladder to treat incontinence after transurethral resection of the prostate (TURP). The pressure-regulating balloon is best implanted intraperitoneally to enable optimal transmission of the abdominal pressure. Alternatively, it can be placed in the cavity of Retzius (retropubic space), as some surgeons prefer to do because of the shorter operating time. The pump mechanism and the control unit are placed in the scrotum.

The patient must be adequately informed before surgery in order for the implantation and use of a hydraulic sphincter to succeed. The patient will need to muster a certain degree of manual dexterity and mental compliance to be able to use the system independently after surgery. Contraindications include poor tissue quality at the site of the prospective implant, infection, subvesical obstruction with residual urine volume, detrusor hyperactivity, and a bladder capacity of less than $200 \mathrm{~mL}$.

The observed functional outcome is an improvement of continence, with the use of no more than one incontinence pad per day, in $75 \%$ to $90 \%$ of patients undergoing the procedure (18-20). There are, however, a number of potential complications. Artificial sphincters are fraught with a considerable risk of infection. One reason for this is the site of implantation (next to the urethra), another is the large volume of foreign material that has to be implanted. Reported infection rates in the literature range from $1.8 \%$ to $10 \%(21,22)$. Furthermore, circumferential pressure on the urethra 
causes tissue atrophy in the long term, and this can actually worsen stress incontinence to an extent that necessitates reoperation. A need for revision owing to this intrinsic drawback of the system arises in as many as $9 \%$ of all patients so treated (23). Urethral erosion by the cuff, when it arises, is a serious complication that usually necessitates total removal of the system; its frequency, which partly depends on the surgeon's experience with the system, has been reported at $1 \%$ to $8.1 \%$ $(22,24)$. The hydraulic sphincter, a mechanical system with three components, is subject to continual wear and tear. In a recent study, Kim et al. (22) documented a $23.4 \%$ rate of system defects, although rates in the older literature were approximately 8\% (25). System defects are thus the reason for about half of all revision procedures for artificial sphincter systems.

Despite these rather high rates of complications and reinterventions, the subjective rate of satisfaction is $85 \%$ to $95 \%$ among patients with artificial sphincters for the treatment of incontinence after radical prostatectomy (19). The relevant studies are summarized in Table 5.

\section{Overview}

Pelvic floor training should always be used as primary treatment, with or without biofeedback. Even though this form of therapy does not yield a higher long-term success rate than the spontaneous course of the condition, it does shorten the period of time in which the patient is incontinent. Pharmacotherapy is currently a matter of great interest, but no general recommendation can be made yet on the basis of the available data. The same can be said of paraurethral injection therapy, which can sometimes shorten the postoperative period of incontinence but does not alter the long-term prognosis. Some of the current surgical treatments, including balloon compression and sling plasties, have shown promising results. The artificial sphincter remains the gold standard of treatment for intractable stress incontinence in men, despite its rather high complication rate and the availability of newer, less invasive techniques. Table 6 contains a summary of the evidence levels and recommendation grades of each of the treatments discussed in this article.

\section{Conflict of interest statement \\ PD Dr. Sperling has received lecture honoraria from American Medical Systems. Dr. Kaufmann has received lecture honoraria from Medtronic. Dr. Börgermann, Prof. Stöhrer, and Prof. Rübben state that they have no conflict of interest as defined by the International Committee of Medical Journal Editors.}

Manuscript submitted on 5 January 2009, revised version accepted ion on 23 February 2010.

Translated from the original German by Ethan Taub, M.D.

\section{REFERENCES}

1. Burkhard FC, Kessler TM, Fleischmann A, Thalmann GN, Schumacher M, Studer UE: Nerve sparing open radical retropubic prostatectomy-does it have an impact on urinary continence? J Urol 2006; 176(1): 189-95.

\section{KEY MESSAGES}

- Many men suffer from stress incontinence after radical prostatectomy.

- The subject of incontinence in men is still often wrongly regarded as taboo.

- Stress incontinence after radical prostatectomy often takes a favorable spontaneous course.

- Therefore, an adequate trial of conservative therapy should be given before any surgical procedure is considered.

- Incontinence requires treatment.

2. Rudy DC, Woodside JR, Crawford ED: Urodynamic evaluation of incontinence in patients undergoing modified Campbell radical retropubic prostatectomy: a prospective study. J Urol 1984; 132(4): 708-12.

3. Wei JT, Dunn RL, Sandler HM, et al.: Comprehensive comparison of health-related quality of life after contemporary therapies for localized prostate cancer. J Clin Oncol 2002; 20(2): 557-66.

4. Hampel C, Gillitzer R, Wiesner C, Thuroff JW: Established treatment options for male stress urinary incontinence. Urologe A 2007; 46(3): 244-46

5. Van Kampen M, De Weerdt W, Van Poppel H, Baert L: Urinary incontinence following transurethral, transvesical and radical prostatectomy. Retrospective study of 489 patients. Acta Urol Belg 1997; 65(4): 1-7.

6. Fowler FJ, Jr., Barry MJ, Lu-Yao G, Wasson J, Roman A, Wennberg J: Effect of radical prostatectomy for prostate cancer on patient quality of life: results from a Medicare survey. Urology 1995; 45(6): 1007-13.

7. Hampel C, Artibani W, Espuna PM, et al.: Understanding the burden of stress urinary incontinence in Europe: a qualitative review of the literature. Eur Urol 2004; 46(1): 15-27.

8. Bauer RM, Bastian PJ, Gozzi C, Stief CG: Postprostatectomy incontinence: all about diagnosis and management. Eur Urol 2009; 55(2): 322-33.

9. Hunter KF, Moore KN, Cody DJ, Glazener CM: Conservative management for postprostatectomy urinary incontinence. Cochrane Database Syst Rev 2004;(2): CD001843.

10. Moore KN, Cody DJ, Glazener CM: Conservative management for post prostatectomy urinary incontinence. Cochrane Database Syst Rev 2001;(2): CD001843.

11. Yokoyama T, Nishiguchi J, Watanabe T, et al.: Comparative study of effects of extracorporeal magnetic innervation versus electrical stimulation for urinary incontinence after radical prostatectomy. Urology 2004; 63(2): 264-7.

12. Filocamo MT, Li M, V, Del Popolo G, et al.: Pharmacologic treatment in postprostatectomy stress urinary incontinence. Eur Urol 2007: 51(6): 1559-64.

13. Schneider T, Sperling H, Rossi R, Schmidt S, Rubben H: Do early injections of bulking agents following radical prostatectomy improve early continence? World J Urol 2005; 23(5): 338-42.

14. Bross S, Kwon ST, Peter S, Honeck P: New techniques for surgical treatment of postoperative male stress incontinence. Urologe A 2007; 46(3): 257-3.

15. Hampel C, Hohenfellner M, Melchior S, Thuroff JW: Sling-plasty in therapy of female urinary incontinence. Urologe A 2001; 40(4): 274-80.

16. Scott FB, Bradley WE, Timm GW: Treatment of urinary incontinence by implantable prosthetic sphincter. Urology 1973; 1(3): 252-9. 
17. Craggs MD, Chaffey NJ, Mundy AR: A preliminary report on a new hydraulic sphincter for controlling urinary incontinence. J Med Eng Technol 1991; 15(2): 58-62.

18. Fleshner $\mathrm{N}$, Herschorn $\mathrm{S}$ : The artificial urinary sphincter for postradical prostatectomy incontinence: impact on urinary symptoms and quality of life. J Urol 1996; 155(4): 1260-4.

19. Perez LM, Webster GD:Successful outcome of artificial urinary sphincters in men with post-prostatectomy urinary incontinence despite adverse implantation features. J Urol 1992; 148(4): 1166-70.

20. Trigo-Rocha F, Gomes CM, Pompeo AC, Lucon AM, Arap S: Prospective study evaluating efficacy and safety of Adjustable Continence Therapy (ProACT) for post radical prostatectomy urinary incontinence. Urology 2006; 67(5): 965-9.

21. Montague DK: The artificial urinary sphincter (AS 800): experience in 166 consecutive patients. J Urol 1992; 147(2): 380-2.

22. Kim SP, Sarmast Z, Daignault S, Faerber GJ, McGuire EJ, Latin JM: Long-term durability and functional outcomes among patients with artificial urinary sphincters: a 10-year retrospective -review from the University of Michigan. J Urol 2008; 179(5): 1912-6.
23. Litwiller SE, Kim KB, Fone PD, White RW, Stone AR: Postprostatectomy incontinence and the artificial urinary sphincter: a long-term study of patient satisfaction and criteria for success. J Urol 1996; 156(6):1975-80.

24. Elliott DS, Barrett DM: Mayo Clinic long-term analysis of the functional durability of the AMS 800 artificial urinary sphincter: a review of 323 cases. J Urol 1998; 159(4):1206-8.

25. Leo ME, Barrett DM: Success of the narrow-backed cuff design of the AMS800 artificial urinary sphincter: analysis of 144 patients. $J$ Urol 1993; 150(5 Pt 1):1412-4.

Corresponding author

Dr. med. Christof Börgermann

Klinik und Poliklinik für Urologie

Krankenhaus Düren gGmbH

Roonstr 30

52351 Düren, Germany

christof.boergermann@krankenhaus-dueren.de

For eReferences please refer to: www.aerzteblatt-international.de/ref2710 


\title{
The Treatment of Stress Incontinence in Men
}

\author{
Part 2 of a Series of Articles on Incontinence
}

Christof Börgermann, Albert Kaufmann, Herbert Sperling, Manfred Stöhrer, Herbert Rübben

\section{eReferences}

e1. Nitti VW, Blaivas JG: Urinary Incontinence. In: Walsh P, Retik A, Vaughan ED, Wein A, eds.: Campbell's Urology. New York: Saunders 2010: 2047-9.

e2. Schröder A, Andersson K-E, Artibani W et al.: Guidlines on Urinary Incontinence. 2009.

e3. Diokno AC, Taub M: Ephedrine in treatment of urinary incontinence. Urology 1975; 5(5):624-5.

e4. Nito H. Clinical effect of midodrine hydrochloride on the patients with urinary incontinence. Hinyokika Kiyo 1994; 40(1):91-4.

e5. Noguchi M, Eguchi Y, Ichiki J, Yahara J, Noda S: Therapeutic efficacy of clenbuterol for urinary incontinence after radical prostatectomy. Int J Urol 1997; 4(5):480-3.

e6. Zozikov B, Kunchev SI, Varlev C. Application of clenbuterol in the treatment of urinary incontinence. Int Urol Nephrol 2001; 33(3): 413-6.

e7. Reid GF, Fitzpatrick JM, Worth PH: The treatment of patients with urinary incontinence after prostatectomy. Br J Urol 1980; 52(6): 532-4.

e8. Schlenker B, Gratzke C, Reich O, Schorsch I, Seitz M, Stief CG: Preliminary results on the off-label use of duloxetine for the treatment of stress incontinence after radical prostatectomy or cystectomy. Eur Urol 2006; 49(6): 1075-8.

e9. Zahariou A, Papaioannou P, Kalogirou G: Is HCl duloxetine effective in the management of urinary stress incontinence after radical prostatectomy? Urol Int 2006; 77(1): 9-12.

e10. Kylmala T, Tainio H, Raitanen M, Tammela TL: Treatment of postoperative male urinary incontinence using transurethral macroplastique injections. J Endourol 2003; 17(2): 113-5.

e11. Imamoglu MA, Tuygun C, Bakirtas H, Yigitbasi O, Kiper A: The comparison of artificial urinary sphincter implantation and endourethral macroplastique injection for the treatment of postprostatectomy incontinence. Eur Urol 2005; 47(2):209-13.

e12. Alloussi S: Preleminary results of non-animal stabilised hyaluronic acid/dextranomer (Nasha./DX) gel for posprostatectomy incontinence. Eur Urol 2005; 4(Suppl): 76. e13. Hubner WA, Schlarp OM: Treatment of incontinence after prostatectomy using a new minimally invasive device: adjustable continence therapy. BJU Int 2005; 96(4):587-94.

e14. Lebret T, Cour F, Benchetrit J, Grise P, Bernstein J, Delaporte V et al.: Treatment of postprostatectomy stress urinary incontinence using a minimally invasive adjustable continence balloon device, ProACT: results of a preliminary, multicenter, pilot study. Urology 2008; 71(2):256-60.

e15. Kempkensteffen C, Hinz S, Christoph F, Weikert S, Schrader M, Schostak M: Rectal perforation as a late complication of ProACT implantation. Urologe A 2006; 45(7):865-7.

e16. Thuroff JW, Hohenfellner M, Schultz-Lampel D: Operative Technik der Faszienzügelplastik beim Mann. Aktuel Urol 1992; 23.

e17. Madjar S, Jacoby K, Giberti C, Wald M, Halachmi S, Issaq E et al.: Bone anchored sling for the treatment of post-prostatectomy incontinence. J Urol 2001; 165(1):72-76.

e18. Fassi-Fehri H, Badet L, Cherass A, Murat FJ, Colombel M, Martin $X$ et al.: Efficacy of the InVance male sling in men with stress urinary incontinence. Eur Urol 2007; 51(2):498-503.

e19. Sousa-Escandon A, Cabrera J, Mantovani F, Moretti M, loanidis E, Kondelidis $\mathrm{N}$ et al.: Adjustable suburethral sling (male remeex system) in the treatment of male stress urinary incontinence: a multicentric European study. Eur Urol 2007; 52(5):1473-1479.

e20. Romano SV, Metrebian SE, Vaz F, Muller V, D'Ancona CA, Costa DE Souza EA et al.: An adjustable male sling for treating urinary incontinence after prostatectomy: a phase III multicentre trial. BJU Int 2006; 97(3):533-539.

e21. de Leval J, Waltregny D: The Inside-Out Trans-Obturator Sling: A Novel Surgical Technique for the Treatment of Male Urinary Incontinence. Eur Urol 2007.

e22. Rehder P, Gozzi C: Transobturator sling suspension for male urinary incontinence including post-radical prostatectomy. Eur Urol 2007; 52(3):860-866.

e23. Gozzi C, Becker AJ, Bauer R, Bastian PJ: Early results of transobturator sling suspension for male urinary incontinence following radical prostatectomy. Eur Urol 2008; 54(4):960-1. 